\title{
Properties and Functions of Feline Herpesvirus Type 1 Glycoproteins
}

\author{
Ken MAEDA, Taisuke HORIMOTO ${ }^{1)}$ and Takeshi MIKAMI ${ }^{2}$ \\ Department of Veterinary Microbiology, Faculty of Agriculture, Yamaguchi University, 1677-1 Yoshida, Yamaguchi-city, Yamaguchi \\ 753-8515, 'Department of Veterinary Microbiology, Osaka Prefecture University, 1-1 Gakuen-cho, Sakai, Osaka 599-8531, and \\ ${ }^{2}$ Department of Veterinary Microbiology, Faculty of Agriculture, The University of Tokyo, 1-1-1 Yayoi, Bunkyo-ku, Tokyo 113-8657, \\ Japan
}

(Received 27 January 1998/Accepted 24 April 1998)

ABSTRACT. Feline herpesvirus type 1 (FHV-1) is a causative agent of feline viral rhinotracheitis and belongs to the subfamily Alphaherpesvirinae of the family Herpesviridae. Since first isolated in 1958 by Crandell and Maurer, FHV-1 is distributed worldwide and is the most clinically significant agent for respiratory infections in cats. In this review, we describe the recent findings with properties and functions of FHV-1 glycoproteins, especially hemagglutinins. - KEY wORDS: feline herpesvirus type 1, glycoprotein, hemagglutinin. J. Vet. Med. Sci. 60(8): 881-888, 1998

In 1958, Crandell and Maurer [13] isolated an agent from kittens (Felis catus) with an acute upper respiratory tract disease in the United States. The agent causes cytopathic effects in feline kidney cell cultures characterized by polykaryocytosis and formation of intranuclear inclusion bodies in fixed-stained preparations. The designation of "feline viral rhinotracheitis (FVR)" was proposed for the disease [12]. Subsequent works supported Crandell's view that the virus should be classified in the Herpesviridae [5, 16] and defined as feline herpesvirus type 1 (FHV-1) [69]. Since the original isolation, FHV-1 has been shown to be the most clinically significant pathogen for respiratory infections in cats [63]. In Japan, the outbreak of the infection was first reported in a colony of cats used for an experimental purpose in 1974 [17].

FVR caused by FHV-1 is a typically acute, febrile, contagious disease of felids characterized by sneezing with ocular and nasal discharges. The incubation period is 2-4 days, and sometimes longer. Mortality is higher in young or debilitated cats, but most of them recover within 7-10 days. The disease is common and widespread in the world. Earlier serological surveys showed that serum neutralizing antibody to FHV-1 is detectable in $50-75 \%$ of cat population $[65,79]$. In Japan, $20 \%$ of the sera of cats for experimental use were positive for FHV-1 antibodies [93].

FHV-1 infection in cats is largely controlled by the use of modified live or inactivated vaccines containing FHV-1 alone or combination with feline calicivirus and feline panleukopenia virus $[1-3,7,14,18,19,21,64,66,73-75$, $92,94]$. None of the vaccines so far developed has been able to provide complete protection in terms of preventing viral replication on re-exposure, but clinical protection is adequately provided. It is unknown whether vaccination can prevent the establishment of a carrier state [22, 62].

FHV-1 is classified as a member of subfamily Alphaherpesvirinae, family Herpesviridae [69]. Using negative staining of the virions $[16,52,54,88]$ or ultrathin sectioning of FHV-1-infected cells [11, 54], mature virus particles are $120-180 \mathrm{~nm}$ in diameter, with various morphologies in shapes and sizes of the envelope surrounding the hexagonal outline of the capsid.

The genome of FHV-1 consists of approximately 126$134 \mathrm{kbp}$. It has a $\mathrm{G}+\mathrm{C}$ content of approximately $50 \%$. The genome is divided into two unique portions, the unique long $\left(\mathrm{U}_{\mathrm{L}}\right)$ and unique short $\left(\mathrm{U}_{\mathrm{S}}\right)$ regions, by inverted repeat segments (IR) (Fig. 1) [24, 70]. The $U_{L}$ is $99-104 \mathrm{kbp}$ in size and is composed of unique DNA. The adjacent short segment is approximately $27-30 \mathrm{kbp}$ in size and contains a central portion of Us which is approximately $8-9 \mathrm{kbp}$ in size. The Us region is bounded by inverted repeat sequences of 7-11 kbp.

We have already introduced review articles on recombinant viral vector vaccines for the veterinary use [97] and molecular interactions between retroviruses and herpesviruses [30]. Therefore, this review mainly focuses on some of the recent developments regarding properties and functions of FHV-1 glycoproteins including hemagglutinin.

\section{HEMAGGLUTININ TO FELINE RED BLOOD CELL (RBC)}

FHV-1 replicates readily in all the cells of feline origin so far tested, which include primary and secondary cell cultures or established cell lines, originated from kidney, thymus, tongue, lung, T-lymphocytes, and neurofibrosarcoma [13, 26, 32, 33, 83]. By contrast, FHV1 does not replicate in the cells of non-feline origin. There is one report describing adsorptive infection of FHV-1 in human cells [81]. FHV-1 attaches but does not penetrate to human embryonic lung cells, which are naturally resistance to the virus, and following treatment with inactivated Sendai virus, the virus causes characteristic cytopathic effects in 
A

UL

B

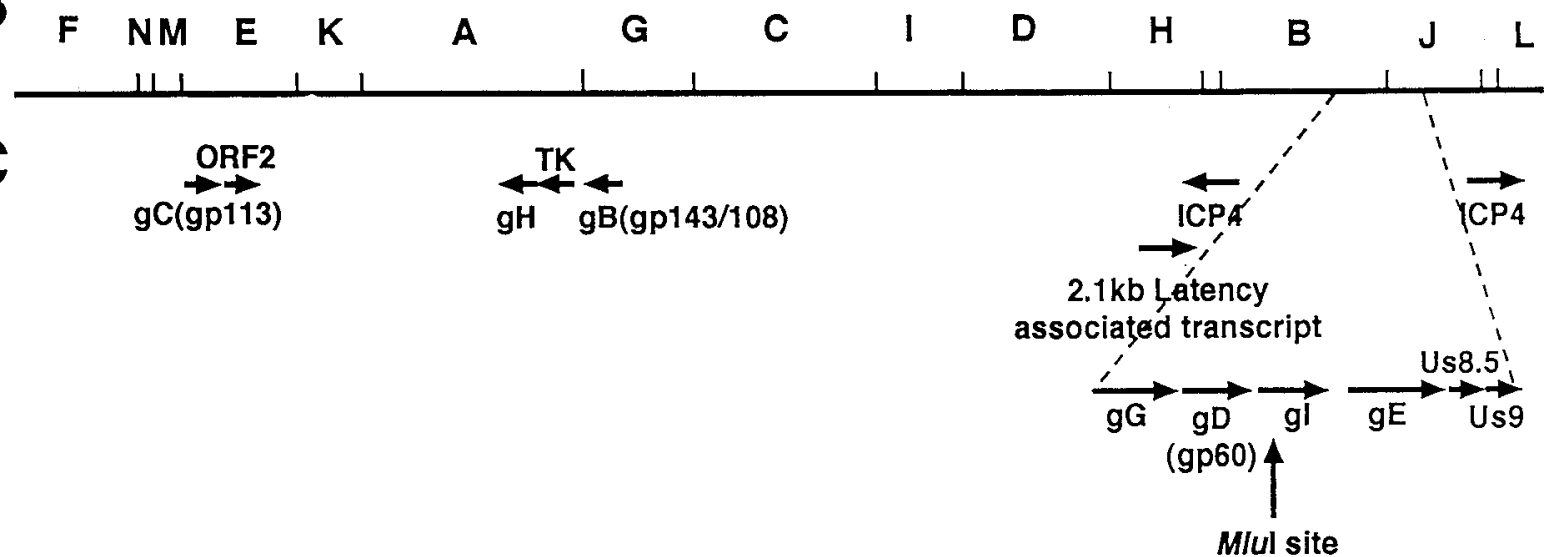

Fig. 1. Location of genes mapped in FHV-1. (A) Schematic diagram of the FHV-1 genome. Open boxes represent inverted repeat regions $\left(I_{S}=\right.$ internal repeat; $T R_{S}=$ terminal repeat) that separate the unique long $\left(U_{L}\right)$ from the unique short $\left(U_{S}\right)$ component. $(B)$ SalI-restriction fragment map [70]. (C) Location of genes. Horizontal arrows indicate transcriptional direction. A vertical arrow shows the heterogeneous $M l u I$ site.

Table 1. Hemagglutinins of herpesviruses

\begin{tabular}{lcclc}
\hline Virus & Natural host & Hemagglutinin & $\mathrm{RBC}$ & Inhibition of HA activity by heparin \\
\hline \multirow{2}{*}{ FHV-1 } & feline & $\mathrm{gD}$ & feline & - \\
& & $\mathrm{gC}$ & mouse & + \\
CHV & canine & $\mathrm{gD}$ & canine & - \\
& & $\mathrm{gC}$ & mouse & + \\
EHV-1 & equine & $?$ & equine & $?$ \\
ILTV & chicken & $?$ & chicken & $?$ \\
HSV-1 & human & $\mathrm{gC}$ & mouse & + \\
BHV-1 & bovine & $\mathrm{gC}$ & mouse & + \\
PRV & porcine & $\mathrm{gC}$ & mouse & + \\
\hline
\end{tabular}

the cells without releasing infectious virus [81], indicating that penetration step to the cells may regulate FHV-1 cell tropism. In vivo the host range appears to be confined to members of the Felidae, unlike other alphaherpesviruses such as herpes simplex virus 1 (HSV-1) and pseudorabies virus (PRV). However, it is unknown what factors govern the narrow host range. Here we discuss on a possible contribution of FHV-1 hemagglutinin as a candidate for determining the restricted host range.

FHV-1 agglutinates only feline RBC, but not chicken, guinea pig, and canine RBCs [23, 25, 55]. Other alphaherpesviruses, canine herpesvirus ( $\mathrm{CHV}$ ), equine herpesvirus type $1(\mathrm{EHV}-1)$ and infectious laryngotracheitis virus (ILTV), also agglutinate RBCs from respective hosts [51, 56, 67]. Like FHV-1, these three viruses have very narrow host ranges. It is possible that such interaction of virus-to-RBCs may reflect characteristics of herpesvirus host ranges (Table 1).

Gillespie et al. [23] first reported that FHV-1, propagated in primary feline cells or diploid feline tongue cells, shows hemagglutination (HA) activity on feline $\mathrm{RBC}$ at 4, 20, and $37^{\circ} \mathrm{C}$, although its titer is low. Treatment of the virus with tween 80 and ethyl-ether enhances HA activity, indicating that hemagglutinin is an envelope protein. The receptors on feline RBCs are destroyed by trypsin, suggesting a protein in nature [55]. The correlation between virus-neutralization (VN) and HA-inhibition (HI) antibodies in the sera from FHV-1-infected cats is demonstrated [55]. HI test can be used for a serological survey on FHV-1 infection in cats [93]. By solubilization of virus-infected cells with detergents, such as Triton X-100, sodium deoxycholate, or 3-[(3-cholamido-propyl) dimetyl-ammonio]-1propanesulfinate (CHAPS), high titered hemagglutinins are successfully obtained [25].

By ConA-sepharose, ion-exchange, and gel-exclusion chromatographies, an approximately $59 \mathrm{kDa}$ immunogenic glycoprotein (later termed gp60) is purified as a hemagglutinin [25]. Three monoclonal antibodies (MAbs) 
against FHV-1 gp60 possessed $\mathrm{HI}$ activities, confirming that the gp60 is the hemagglutinin [27]. A transient expression system with FHV-1 gD in COS-7 cells reveals that its product reacts with MAbs only against gp60 and agglutinates feline RBC [41]. Feline RBC adsorbs to the surface of insect cells infected with a recombinant baculovirus expressing gD. Following immunization of the insect cells expressing gD in mice, the animals produce $\mathrm{HI}$ antibodies in the sera [44]. Taken together, FHV-1 gD is confirmed to be the hemagglutinin to feline RBC.

Additionally, the insect cells expressing $\mathrm{gD}$ adhere to cell lines of feline-origin, but not to those of non-feline originated [45], indicating existence of a specific interaction between FHV-1 gD and molecules on the surface of the former. Therefore, the FHV-1 gD might be one of the factors determining host range of FHV-1.

Like FHV-1, CHV possesses narrow host range; dog is the only known natural host. The virus grows exclusively in cell types of only canine origin such as primary canine kidney cell cultures and Madin-Darby canine kidney (MDCK) cell line [6, 10, 62, 78]. CHV gD adsorbs to canine RBC, not to feline RBC [47]. Although a common epitope is demonstrated between FHV-1 and CHV gDs by an MAb, which has a complement-independent VN activity to both viruses [36], different HA properties between these two gDs provide a notion that the $\mathrm{gD}$ may regulate the narrow host range of each virus at the cell-receptor levels.

\section{HEMAGGLUTININ TO MOUSE RBC}

Culture supernatants of HSV-1-, bovine herpesvirus type 1 (BHV-1)-, and PRV-infected cells agglutinate mouse RBC, and these HA activities are inhibited by treatment of hemagglutinin with heparin or by treatment of mouse RBC with heparinase $[29,57-59,82,84,85]$. It was reported that $\mathrm{gCs}$ of these viruses are responsible for their HA activities (Table 1) [50, 58, 59, 84, 85].

Culture fluid from FHV-1-infected Crandell's feline kidney (CRFK) cells agglutinate mouse RBC. However, this HA activity to mouse RBC is not inhibited by HI MAbs to feline $\mathrm{RBC}$, which recognize FHV-1 gD, indicating the hemagglutinin to mouse $\mathrm{RBC}$ is not the $\mathrm{gD}$ [our unpublished data].

In FHV-1, addition of heparin to virus inoculum inhibits its infectivity to CRFK cells, suggesting that heparan sulfate on the surface of this cell line is a responsible factor for virus attachment to the cells, like other herpesviruses. Two FHV-1 glycoproteins, $\mathrm{gC}$ and $\mathrm{gB}$, are able to bind to column containing heparin-agarose and are eluted with heparin, although the latter is also detected in non-binding fraction. These results indicate that the $\mathrm{gC}$ binds to heparan sulfate on the cell surface [48]. Mouse RBC, not feline RBC, adsorbs to the COS-7 cells expressing FHV-1 gC. This hemadsorption is inhibited by addition of heparin but not HI MAbs to feline RBC. By contrast, HA to feline RBC is not inhibited by addition of heparin [our unpublished data]. Taken together, the hemagglutinin to mouse RBC is the $\mathrm{gC}$. Thus, FHV-1 contains two hemagglutinins; heparin-sensitive $\mathrm{gC}$ and -insensitive $\mathrm{gD}$.

\section{VIRAL GLYCOPROTEINS}

Sodium dodecyl sulfate (SDS)-polyacrylamide gel electrophoresis (PAGE) analysis reveals 23 proteins in the whole FHV-1 particle [20]. Of them, 6 glycoproteins of $125,116,112,83,70$, and 60 kilodalton $(\mathrm{kDa})$ are included. Maes et al. [49] reported 17 virus-specific proteins, and 3 immunogenic glycoproteins of 105, 68, and $60 \mathrm{kDa}$, which react with a goat anti-FHV-1 serum as well as virus-infected cat sera [4]. Compton [9] described 5 glycoproteins of 107, $103,85,68$, and $59 \mathrm{kDa}$, in association with virus-infected cell extracts or purified virions. In addition, the $107 \mathrm{kDa}$ and a novel $75 \mathrm{kDa}$ are observed in culture supernatants. Horimoto et al. [27] identified four groups of the immunogenic proteins by use of MAbs to FHV-1. MAbs directed to 60,113 , and $143 / 108 \mathrm{kDa}$ glycoproteins have $\mathrm{VN}$ activities, but those to $170 \mathrm{kDa}$ protein do not. Additionally, MAbs to the $60 \mathrm{kDa}$ also show HI activity to feline RBC.

At least four FHV-1 glycoprotein genes are localized in

Table 2. Glycoproteins of FHV-1

\begin{tabular}{|c|c|c|c|}
\hline Glycoproteins & Location & VN activity & Remarks \\
\hline $\mathrm{gD}$ & $\mathrm{U}_{\mathrm{S}}$ & $+\left(-C^{\prime a},+C^{\prime b}\right)$ & $\begin{array}{l}\text { Hemagglutinin to feline } \mathrm{RBC} \\
\text { Binding to feline-originated cell lines }\end{array}$ \\
\hline $\mathrm{gB}$ & $\mathrm{U}_{\mathrm{L}}$ & $+\left(+C^{\prime}\right)$ & $\begin{array}{l}\text { A disulfide-linked complex } \\
\text { Binding to heparin (?) }\end{array}$ \\
\hline $\mathrm{gC}$ & $\mathrm{U}_{\mathrm{L}}$ & $+\left(+C^{\prime}\right)$ & $\begin{array}{l}\text { Hemagglutinin to mouse RBC } \\
\text { Binding to heparin }\end{array}$ \\
\hline $\mathrm{gH}$ & $\mathrm{U}_{\mathrm{L}}$ & $?$ & $?$ \\
\hline $\mathrm{gI}$ & $\mathrm{U}_{\mathrm{S}}$ & $?$ & $\begin{array}{l}\text { Nonessential for viral-replication in cell culture } \\
\text { Complex with gE }\end{array}$ \\
\hline $\mathrm{gE}$ & $\mathrm{U}_{\mathrm{S}}$ & $?$ & $\begin{array}{l}\text { Nonessential for viral-replication in cell culture } \\
\text { Complex with gI }\end{array}$ \\
\hline $\mathrm{gG}$ & $\mathrm{U}_{\mathrm{S}}$ & $?$ & $?$ \\
\hline
\end{tabular}

$-C^{\prime a}$ : Complement-independent virus-neutralizing activity.

$+\mathrm{C}^{\mathrm{b}}$ : Complement-dependent virus-neutralizing activity. 
the $\mathrm{U}_{\mathrm{S}}$ region (Fig. 1) $[41,77,91]$. Three more glycoprotein genes are localized in the $\mathrm{U}_{\mathrm{L}}$ region $[39,40,46,76]$. The seven glycoproteins found in FHV-1 so far are designated $\mathrm{gB}, \mathrm{gC}, \mathrm{gD}, \mathrm{gE}, \mathrm{gI}, \mathrm{gH}$, and $\mathrm{gG}$ (Table 2), all of which constitute homologues of other herpesvirus glycoproteins. Of them, at least $\mathrm{gI}$ and $\mathrm{gE}$ are shown to be nonessential for viral replication in tissue cultures [80, 89].

3-1. gD (gp60)

We described HA property of gD in detail in the section of "HEMAGGLUTININ TO FELINE RBC". MAbs to gD show complement-independent $\mathrm{VN}$ activities [27]. A competitive enzyme-linked immunosorbent assay (ELISA) with MAbs reveals at least four different epitopes on the $\mathrm{gD}$ [35]. Affinity-purified gD induces $\mathrm{VN}$ antibodies in mice [37], and high titers of VN antibodies are also generated in rabbits inoculated with the recombinant vaccinia virus expressing gD [76]. Additionally, mice immunized with recombinant baculovirus-infected cells expressing gD, possess high titers of VN antibodies [44]. Thus, FHV-1 gD appears to be one of the most primary candidates for subunit vaccine against FHV-1 infection.

gDs of some herpesviruses are indispensable for virus growth in vitro and in vivo, but their biological functions are quite different each other. For example, in HSV-1, gDnegative mutant virus is not able to infect susceptible cells and does not spread by direct cell-to-cell transmission [34]. Conversely, although PRV gD negative mutant virus does not infect cell lines sensitive to PRV infection, the virus spreads by direct cell-to-cell transmission [68]. A recent report [72] however proved that high-passaged gD-deleted PRV can grow in cell cultures, indicating that PRV $\mathrm{gD}$ is not essential for viral growth. Meanwhile, varicello-zoster virus (VZV) lacks a gene of $\mathrm{gD}$ counterpart [15]. In Marek's disease virus (MDV), a transcriptional product of the $\mathrm{gD}$ gene is not obvious by northern blot analysis, although a low level expression of $\mathrm{gD}$ is detected in chicken embryo fibroblasts infected with a low passage of virulent strains by indirect immunofluorecence and western blot analyses [60]. Additionally, as described above, FHV-1 gD and $\mathrm{CHV}$ gD agglutinate feline RBC and canine RBC, respectively. Such different biological functions of alphaherpesvirus $\mathrm{gD}$ counterparts may result in unique characteristics of each virus.

Identification of cell surface molecules that bind specifically to these gDs must be useful for analyses of initial process for herpesvirus infection to susceptible cells contributing to determination of host ranges of herpesviruses.

3-2. gB (gp143/108)

SDS-PAGE analysis shows that gB (gp143/108) in virusinfected cells has molecular masses of 143 and $108 \mathrm{kDa}$ under non-reducing conditions and those of 108, 70, 64, and $58 \mathrm{kDa}$ under reducing conditions [27, 38]. Of them, $108 \mathrm{kDa}$ glycoprotein is not incorporated to virion. Three of the nine MAbs against $\mathrm{gB}$ possess complement-dependent VN activities [27]. A competitive ELISA with MAbs reveals only one antigenic site consisting of five similar or overlapping epitopes on the $\mathrm{gB}$ [35]. Purified $\mathrm{gB}$ induces high titers of VN antibodies in mice [37]. Vaccinia virus expressing $\mathrm{gB}$ induces fairly high titers of $\mathrm{VN}$ antibodies in rabbits [76]. When the expression plasmid of FHV $-1 \mathrm{gB}$ is inoculated intramuscularly into mice, a specific antibody against $\mathrm{gB}$ is induced [38]. Therefore FHV-1 $\mathrm{gB}$ appears to be also one of the most important candidates for subunit vaccine against FHV-1 infection.

Processing of FHV-1 gB has not been fully elucidated. Amino acid sequence of FHV-1 gB shows that there are two potential cleavage sites (RTRR/S and RSRR/S) by intracelluler endoproteases [76]. Authentic cleavage of these two sites is unknown. However, because FHV-1 gB seems to be a heterodimer, either or both sites must be cleaved. Herpesvirus gBs are one of the most conservative proteins beyond three herpesvirus subfamilies, such as Alpha-, Betaand Gammaherpesvirinae. Evolutionary trees generated by using 15 herpesvirus gBs show that FHV-1 gB is closer to those of genus Varicello, EHV-1, EHV-4, PRV, BHV-1, and VZV than to those of genus Simplex, HSV-1 and HSV$2[39,76]$, indicating that FHV-1 should be classified in the former genus.

FHV $-1 \mathrm{gB}$ is immunoprecipitated by monospecific rabbit anti-HSV-1 gB sera [76], and is recognized by MAbs against $\mathrm{CHV}$ gB [36]. Thus, FHV-1 gB shares common antigenic epitope(s) with HSV-1 gB or CHV gB. HSV-1 gB is essential for virus adsorption, penetration process to the cells, and cell-to-cell spread. Further analyses will be required to determine functions of $\mathrm{gB}$ for FHV-1 replication. 3-3. gC (gp113)

We described HA property of $\mathrm{gC}$ in detail in the section of "HEMAGGLUTININ TO MOUSE RBC". Recently, nucleotide sequences of FHV-1 $\mathrm{gC}$ were determined [46, 90]. The FHV-1 gC expressed in COS-7 or insect cells is recognized by a series of MAbs against FHV-1 gp113, showing that gp113 is the $\mathrm{gC}$. The expressed $\mathrm{gC}$ in COS-7 cells is approximately $125-150$ and $75 \mathrm{kDa}$. This $75 \mathrm{kDa}$ protein is thought to be a precursor form of $\mathrm{gC}$. By $N$ glycanase treatment, a molecular mass of $\mathrm{gC}$ is reduced to approximately $57 \mathrm{kDa}$, indicating that the gC possesses $\mathrm{N}$ linked oligosaccharides [48]. Some MAbs against gC possess complement-dependent VN activities [27]. Affinity purified-gC induces VN antibody in mice [37]. A competitive ELISA with MAbs reveals two antigenic domains, a neutralizing domain consisting of three overlapping epitopes and a non-neutralizing domain on $\mathrm{gC}$ [35].

$\mathrm{gC}$ of one field isolate, 91-58, possesses molecular masses of 130 and $80 \mathrm{kDa}$ instead of 113 and $75 \mathrm{kDa}$ in all other isolates. Sequence analyses reveals that this isolate has additional 26 amino acids in $\mathrm{N}$-terminal region of the $\mathrm{gC}$ [43, our unpublished data]. This insertion must result in an increased molecular mass of this gC. Biological effect of this insertion remains to be elucidated.

3-4. gI and gE

Genes encoding FHV-1 $\mathrm{gI}$ and $\mathrm{gE}$ are located in Us region $[77,91]$. Recombinant vaccinia virus harboring $\mathrm{gI}$ or $\mathrm{gE}$ 
expresses $67 \mathrm{kDa}$ or $82 \mathrm{kDa}$ protein, respectively. These proteins are sensitive to endoglycosidase $\mathrm{H}$ (endo $\mathrm{H}$ ), suggesting that immature forms accumulate in endoplasmic reticulum. Upon co-expression of $\mathrm{gE}$ and $\mathrm{gI}$, the expressed $\mathrm{gE}$ results in conversion into endo H-resistant $\mathrm{gE}$ forms of 95-100 kDa. In case of a single expression of each gene, neither is found on the cell surface, but in case of coexpression, both are found on the cell surface, suggesting that $\mathrm{gE}-\mathrm{gI}$ interaction is required for transport from the endoplasmic reticulum [53]. A recombinant FHV-1, which has insertion of an expression cassette of $\beta$-galactosidase into $C$-terminal region of the gI gene, becomes attenuated in cats, and it produces smaller plaque in cell cultures than a parent virus does [89]. Sussman et al. [80] reported the construction of another recombinant FHV-1 which lacks $C$ terminal region of the gI gene and 5'-transcriptional control and 5 '-encoding regions of the gE gene. The recombinant virus shows a decreased replication in one step growth kinetics and produces very small plaques in cell cultures. Cats inoculated intranasally or subcutaneously with this recombinant FHV-1 respond with only mild clinical signs and induce a strong protective immunity against subsequent virulent FHV-1 challenge [31, 80].

A comparative study among vaccine F2 strain and field isolates reveals the lack of an $M l u \mathrm{I}$ site, which is located in the gI gene in F2 [28, 42] (Fig. 1). This mutation results in one amino acid change. It is unknown whether this change correlates with attenuation of FHV-1.

Willemse et al. [91] observed the presence of two messenger RNAs of $1.6 \mathrm{~kb}$ and $0.9 \mathrm{~kb}$ transcribed from the $\mathrm{gE}$ genes, which are translated into a polypeptide sequence comprising the $C$-terminus region of $\mathrm{gE}$. The significance of this finding, which has not been reported previously for any other herpesviruses, is unclear. It is interesting to see whether these transcripts are actually synthesized and have some biological functions for virus replication.

3-5. $\mathrm{gH}$

A gene of FHV-1 gH and its transcript were identified [40]. Although two expression systems of the gH gene; recombinant baculovirus system or transient expression system with long terminal repeat of Raus sarcoma virus as a promoter, are constructed, no $\mathrm{gH}$ gene product is detected [our unpublished data]. In other herpesviruses, complex formation with $\mathrm{gL}$ is necessary for maturation of $\mathrm{gH}$, indicating that coexpression with $\mathrm{gL}$ counterpart may be required for expression of FHV-1 $\mathrm{gH}$. $\mathrm{gH}$ counterparts are highly conserved among Herpesviridae, and are essential for viral growth in vitro and in vivo, suggesting that FHV-1 $\mathrm{gH}$ might play an important role in infection as well. Further analysis will be expected to clarify this issue.

3-6. gG

Spatz et al. [77] identified an ORF of FHV-1 gG, the predicted molecular mass of whose product is $61.8 \mathrm{kDa}$ in unglycosylated form. In other herpesviruses, gGs are nonessential for viral replication in vitro and in vivo. PRV $\mathrm{gG}$ $(\mathrm{gX})$ is secreted in the supernatant of the virus-infected cell line. $\mathrm{gG}$ is often used as an antigen for type-specific serodiagnosis between EHV-1 and EHV-4, or between HSV1 and HSV-2. A role of herpesvirus $\mathrm{gG}$ in viral infection is unknown.

\section{CONCLUSIVE REMARKS}

Recent studies have provided some novel information on FHV-1 glycoproteins, which might contribute for understanding of molecular basis on virus replication. Compared with other herpesviruses such as HSV and PRV, FHV-1 possesses a unique characteristics of narrow host range. In the present review, we proposed that herpesvirus gD may determine biological properties of each virus such as host range. A unique finding that $\mathrm{FHV}-1$ contains two hemagglutinins, $\mathrm{gD}$ to feline $\mathrm{RBC}$ and $\mathrm{gC}$ to mouse $\mathrm{RBC}$, would provide an experimental model for better understanding of interaction between herpesvirus and cell receptors at initial process of infection.

For prevention of cats from FVR, development of effective, safe and economical vaccines are expected. In the first step for this purpose, the immunogens that elicit VN antibodies must be identified and characterized. In this review, we described that some FHV-1 glycoproteins are included in the immunogens responsible for humoral immune responses in host animal. Additionally, cellular immunity is also important for prevention of herpesvirus infection. This issue should be studied in future.

Recently, FHV-1 recombinants accommodating some antigens of other pathogens have selected, providing a possible use as polyvalent vaccines [8, 71, 86, 87, 95-97] which could be effective to FHV-1 infection itself as well as other infectious diseases in cats. To develop more safe and effective vaccines, non-essential regions of virus replication which can be used for insertion of foreign sequences and virulence determinants whose deletion could result in attenuation of the virus must be determined. Characterization of biological properties of glycoproteins will contribute to these subjects.

ACKNOWLEDGMENTS. These studies cited from authors' laboratory were supported by grants from the Ministry of Education, Science, Sports, and Culture, and from the Ministry of Agriculture, Forestry and Fisheries of Japan. K.M. was supported by Research Aid of Inoue Foundation for Science.

\section{REFERENCES}

1. Bittle, J. L. and Rubic, W. J. 1974. Studies of feline viral rhinotracheitis vaccine. Vet. Med. Small Anim. Clin. 69: 15031505 .

2. Bittle, J. L. and Rubic, W. J. 1975. Immunogenic and protective effects of the F-2 strain of feline viral rhinotracheitis virus. Am. J. Vet. Res. 36: 89-91.

3. Bittle, J. L. and Rubic, W. J. 1975. A feline calicivirus vaccine combined with feline viral rhinotracheitis and feline panleukopenia vaccine. Feline Prac. 5: 13-15. 
4. Burgener, D. C. and Maes, R. K. 1988. Glycoprotein-specific immune responses in cats after exposure to feline herpesvirus-1. Am. J. Vet. Res. 49: 1673-1676.

5. Burki, F., Lindt, S. and Freudiger, U. 1964. Enzootischer, virusbedingter Kataenschnupfen in einum Tierheim 2. Vilologischer und experimenteller Teil. Zentbl. Vet. Med. 11: $110-118$

6. Carmichael, L. E., Strandberg, J. D. and Barnes, F. D. 1965. Identification of a cytopathogenic agent infectious for puppies as a canine herpesvirus. Proc. Soc. Exp. Biol. Med. 120: 644-650.

7. Cocker, F. M., Newby, T. J., Gaskell, R. M., Evans, P. A., Gaskell, C. J., Stokes, C. R., Harbour, D. A. and Bourne, J. F. 1986. Responses of cats to nasal vaccination with a live, modified feline herpesvirus type 1. Res. Vet. Sci. 41: 323330.

8. Cole, G. E., Stacy-Phipps, S. and Numberg, J. H. 1990. Recombinant feline herpesviruses expressing feline leukemia virus envelope and gag proteins. J. Virol. 64: 4930-4938.

9. Compton, T. 1989. Characterization of feline herpesvirus glycoproteins. pp. 45-56. In: Cell Biology of Virus Entry, Replication, and Pathogenesis, vol. 90, (Fox, C.F. ed.), Alan R. Liss, Inc. New York (UCLA symposia on molecular and cellular biology).

10. Cornwell, H. J. C., Weir, A. R., Wright, N. G. and Thompson, H. 1970. The susceptibility of a dog kidney cell-line (MDCK) to canine distemper, infectious canine hepatitis and canine herpesvirus. Res. Vet. Sci. 11: 580-582.

11. Crandell, R. A. 1973. Feline viral rhinotracheitis (FVR). $A d v$. Vet. Sci. Comp. Med. 17: 201-224.

12. Crandell, R. A. and Despeaux, E. W. 1959. Cytopathology of feline viral rhinotracheitis virus in tissue cultures of feline renal cells. Proc. Soc. Exp. Biol. Med. 101: 494-497.

13. Crandell, R. A. and Maurer, F. D. 1958. Isolation of a feline virus associated with intranuclear inclusion bodies. Proc. Soc. Exp. Biol. Med. 97: 487-490.

14. Davis, E. V. and Beckenbauer, W. H. 1976. Studies on the safety and efficacy of an intranasal feline rhinotracheitis-calici virus vaccine. Vet. Med. Small Anim. Clin. 71: 1405-1410.

15. Davison, A. J. and Scott, J. E. 1986. The complete DNA sequence of varicella-zoster virus. J. Gen. Virol. 67: 17591816.

16. Ditchfield, J. and Grinyer, I. 1965. Feline rhinotracheitis virus: a feline herpesvirus. Virology 26: 504-506.

17. Doi, K., Kojima, A., Inami, Y., Yasoshima, A. and Okawa, H. 1974. Feline viral rhinotracheitis in Japan.- Isolation of herpes type virus and pathologic picture. Jpn. J. Vet. Sci. 37: 281-292.

18. Edwards, B. G., Buell, D. J. and Acree, W. M. 1977. Evaluation of a new feline rhinotracheitis virus vaccine. Vet. Med. Small Anim. Clin. 72: 205-209.

19. Edwards, B. G., Buell, D. J., Acree, W. M. and Payne, J. B. 1977. Evaluation of feline rhinotracheitis/feline panleukopenia combination vaccines by consecutive virulent challenge. Feline Prac. 7: 45-50.

20. Fargeaud, D., Jeannin, C. B., Kato, F. and Chappuis, G. 1984. Biochemical study of the feline herpesvirus 1. Identification of glycoproteins by affinity. Arch. Virol. 80: 69-82.

21. Folkers, C. and Hoogenboom, A. M. M. 1978. Intranasal vaccination against upper respiratory tract disease (URD) in the cat. 1. Virological and serological observations in cats suffering from URD. Comp. Immunol. Microbiol. Infect. Dis. 1: $37-41$.
22. Gaskell, R. M. and Povey, R. C. 1979. Feline viral rhinotracheitis: sites of virus replication and persistence in acutely and persistently infected cats. Res. Vet. Sci. 27: 167174.

23. Gillespie, J. H., Judkins, A. B. and Scott, F. W. 1971. Feline viruses. XII. Hemagglutination and hemadsorption tests for feline herpesvirus. Cornell Vet. 61: 159-171.

24. Grail, A., Harbour, D. A. and Chia, W. 1991. Restriction endonuclease mapping of the genome of feline herpesvirus type 1. Arch. Virol. 116: 209-220.

25. Horimoto, T., Kasaoka, T., Tuchiya, K. and Takahashi, E. 1989. Identification of feline herpesvirus type 1-hemagglutinin. Jpn. J. Vet. Sci. 51: 607-612.

26. Horimoto, T., Kawaguchi, Y., Limcumpao, J. A., Miyazawa, T., Takahashi, E. and Mikami, T. 1991. Replication of feline herpesvirus type 1 in feline T-lymphoblastoid cells. J. Vet. Med. Sci. 53: 503-505.

27. Horimoto, T., Limcumpao, J. A., Tohya, Y., Takahashi, E. and Mikami, T. 1990. Feline herpesvirus type 1 glycoproteins eliciting virus neutralizing and hemagglutination-inhibiting antibodies. Arch. Virol. 111: 127132.

28. Horimoto, T., Limcumpao, J. A., Xuan, X., Ono, M., Maeda, K., Kawaguchi, Y., Kai, C., Takahashi, E. and Mikami, T. 1992. Heterogeneity of feline herpesvirus type 1 strains. Arch. Virol. 126: 283-292.

29. Inaba, Y., Tetsu, N., Toriyoshi, H., Yukawa, M., Yoshiki, K., Hirahara, T. and Izumida, A. 1990. Appearance of slow-reacting, complement-requiring hemagglutination-inhibiting antibody in swine infected with pseudorabies virus. Arch. Virol. 113: 115-124.

30. Kawaguchi, Y. and Mikami, T. 1995. Molecular interactions between retroviruses and herpesviruses. [Review] J. Vet. Med. Sci. 57: 801-811.

31. Kruger, J. M., Sussman, M. D. and Maes, R. K. 1996. Glycoproteins $\mathrm{gI}$ and $\mathrm{gE}$ of feline herpesvirus- 1 are virulence genes: Safety and efficacy of a gI-gE- deletion mutant in the natural host. Virology 220: 299-308.

32. Langloss, J. M., Hoover, E. A., Kahn, D. E. and Kniazeff, A. J. 1987. In vitro interaction of alveolar macrophages and pneumocytes with feline respiratory viruses. Infect. Immun. 20: 836-841.

33. Lee, K. M., Kniazeff, A. J., Fabricant, C. G. and Gillespie, J. H. 1969. Utilization of various cell culture systems for propagation of certain feline viruses and canine herpesvirus. Cornell Vet. 59: 538-547.

34. Ligas, M. W. and Johnson, D. C. 1988. A herpes simplex virus mutant in which glycoprotein $\mathrm{D}$ sequences are replaced by $\beta$-galactosidase sequences binds to but is unable to penetrate into cells. J. Virol. 62: 1486-1494.

35. Limcumpao, J. A., Horimoto, T., Takahashi, E. and Mikami, T. 1990. Intracellular localization and epitope mapping of feline herpesvirus type 1 glycoproteins. Jpn. J. Vet. Sci. 52: 351-359.

36. Limcumpao, J. A., Horimoto, T., Xuan, X., Takahashi, E. and Mikami, T. 1990. Immunological relationship between feline herpesvirus type 1 (FHV-1) and canine herpesvirus (CHV) as revealed by polyvalent and monoclonal antibodies. Arch. Virol. 111: 165-176.

37. Limcumpao, J. A., Horimoto, T., Xuan, X., Tohya, Y., Azetaka, M., Takahashi, E. and Mikami, T. 1991. Homologous and heterologous antibody responses of mice immunized with purified feline herpesvirus type 1 and canine herpesvi- 
rus glycoproteins. J. Vet. Med. Sci. 53: 423-432.

38. Maeda, K., Hirasawa, K., Kawaguchi, Y., Ono, M., Mori, T., Gemma, T., Yokoyama, N., Doi, K. and Mikami, T. 1995. Expression and identification of the feline herpesvirus type 1 glycoprotein B (gp143/108). Virus Res. 39: 55-61.

39. Maeda, K., Horimoto, T., Norimine, J., Kawaguchi, Y., Tomonaga, K., Niikura, M., Kai, C., Takahashi, E. and Mikami, T. 1992. Identification and neucleotide sequence of a gene in feline herpesvirus type 1 homologous to the herpes simplex virus gene encoding the glycoprotein B. Arch. Virol. 127: 387-397.

40. Maeda, K., Kawaguchi, Y., Kamiya, N., Ono, M., Tohya, Y., Kai, C. and Mikami, T. 1993. Identification and neucleotide sequence of a gene in feline herpesvirus type 1 homologous to the herpes simplex virus gene encoding the glycoprotein H. Arch. Virol. 132: 183-191.

41. Maeda, K., Kawaguchi, Y., Ono, M., Inoshima, Y., Miyazawa, T., Tohya, Y., Kai, C. and Mikami, T. 1994. A gD homologous gene of feline herpesvirus type 1 encodes a hemagglutinin (gp60). Virology 202: 1034-1038.

42. Maeda, K., Kawaguchi, Y., Ono, M., Tajima, T. and Mikami, T. 1995. Restriction endonucleae analysis of field isolates of feline herpesvirus type 1 and identification of heterogeneous regions. J. Clin. Microbiol. 33: 217-221.

43. Maeda, K., Kawaguchi, Y., Ono, M., Tajima, T. and Mikami, T. 1995. Comparisons among feline herpesvirus type 1 isolates by immunoblot analysis. J. Vet. Med. Sci. 57: 147-150.

44. Maeda, K., Ono, M., Kawaguchi, Y., Niikura, M., Okazaki, K., Yokoyama, N., Tokiyoshi, Y., Tohya, Y. and Mikami, T. 1996. Expression and properties of feline herpesvirus type 1 gD (hemagglutinin) by a recombinant baculovirus. Virus Res. 46: 75-80.

45. Maeda, K., Ono, M., Kawaguchi, Y., Okazaki, K., Yokoyama, M., Tohya, Y. and Mikami, T. 1997. Adhesion of insect cells expressing the feline herpesvirus type 1 hemagglutinin $(\mathrm{gD})$ to feline cell lines. J. Vet. Med. Sci. 59: 217-219.

46. Maeda, K., Yokoyama, N., Fujita, K. and Mikami, T. 1997. Identification and characterization of the feline herpesvirus type 1 glycoprotein C gene. Virus Genes 14: 105-109.

47. Maeda, K., Xuan, X., Kawaguchi, Y., Ono, M., Yokoyama, N., Fujita, K., Tohya, Y., and Mikami, T. 1997. Characterization of canine herpesvirus glycoprotein D (hemagglutinin). $J$. Vet. Med. Sci. 59: 1003-1009.

48. Maeda, K., Yokoyama, N., Fujita, K., Maejima, M. and Mikami, T. 1997. Heparin-binding activity of feline herpesvirus type 1 glycoproteins. Virus Res. 54: 169-176.

49. Maes, R. K., Fritsch, S. L., Herr, L. L. and Rota, P. A. 1984. Immunogenic proteins of feline rhinotracheitis virus. J. Virol. 51: 259-262.

50. Matsuda-Tsuchida, A., Okada, N., Katayama, S., Okabe, T. and Sasaki, N. 1991. The adsorption of pseudorabies virus glycoprotein gIII to the host cell. J. Vet. Med. Sci. 53: 957958.

51. McCollum, W. H., Doll, E. R. and Bryans, J. T. 1956. Agglutination of horse erythrocytes by tissue extracts from hamsters infected with equine abortion virus. Am. J. Vet. Res. 17: 267270.

52. McEwan, P. J. and Miles, J. A. R. 1967. An electron microscope study of viruses associated with upper respiratory tract infections in cats. Proc. Univ. Otago. Med. Sch. 45: 21-23.

53. Mijnes, J. D. F., van der Horst, L. M., Horzinek, M. C., Rottier, P. J. M. and de Groot, R. J. 1995. Heterologous expression of the feline herpesvirus $\mathrm{gE}$ and $\mathrm{gI}$ genes: $\mathrm{gE}-\mathrm{gI}$ interaction is required for intracellular transport. J. Virol. 70: 5466-5475.

54. Mochizuki, M., Konishi, S. and Ogata, M. 1977. Studies on cytopathogenic viruses from cats with respiratory infections. III. Isolation and certain properties of feline herpesviruses. Jpn.J. Vet. Sci. 39: 27-37

55. Mochizuki, M., Konishi, S. and Ogata, M. 1977. Studies on cytopathogenic viruses from cats with respiratory infections. IV. Properties of hemagglutinin in feline herpesvirus suspensions and receptors on feline erythrocytes. Jpn. J. Vet. Sci. 39: 389-395.

56. Nemoto, K., Horimoto, T., Xuan, X., Kusanagi, K., Takumi, A., Tohya, Y., Azetaka, M., Takahashi, E. and Mikami, T. 1990. Demonstration of canine herpesvirus-specific hemagglutination. Jpn. J. Vet. Sci. 52: 395-398.

57. Noda, M., Inaba, Y., Seno, M., Kanamoto, Y. and Tokumoto, S. 1993. Effect of heparin on hemagglutinin of herpes simplex virus type 1. Microbiol. Immunol. 37: 979-981.

58. Okazaki, K., Honda, E, and Kono, Y. 1994. Expression of bovine herpesvirus type 1 glycoprotein gIII by a recombinant baculovirus in insect cells. J. Gen. Virol. 75: 901-904.

59. Okazaki, K., Kanno, T., Kiriya, S., Honda, E. and Kono, Y. 1993. Hemadsorptive activity of transfected COS-7 cells expressing BHV-1 glycoprotein gIII. Virology 193: 666-670.

60. Ono, M., Jang, H. -K., Maeda, K., Kawaguchi, Y., Tohya, Y., Niikura, M. and Mikami, T. 1996. Detection of Marek's disease virus serotype 1 (MDV1) glycoprotein D in MDV1-infected chick embryo fibroblasts. J. Vet. Med. Sci. 58: 777-780.

61. Orr, C. M., Gaskell, C. J. and Gaskell, R. M. 1980. Interaction of an intranasal combined feline viral rhinotracheitis, feline calicivirus vaccine and the FVR carrier state. Vet. Rec. 23: 164-166.

62. Poste, G. 1972. Characterization of a new canine herpesvirus. Arch. Gesamte Virusforsch. 36: 147-157.

63. Povey, R. C. 1976. Feline respiratory infections- a clinical review. Can. Vet. J. 17: 93-100.

64. Povey, R. C. 1977. Feline respiratory disease- which vaccine? Feline Prac. 7: 12-16.

65. Povey, R. C. and Johnson, R. H. 1971. A survey of feline viral rhinotracheitis and feline picornavirus infection in Britain. J. Small Anim. Pract. 12: 233-247.

66. Povey, R. C. and Wilson, M. R. 1978. A comparison of inactivated feline viral rhinotracheitis and feline caliciviral disease vaccines with live-modified viral vaccines. Feline Prac. 8: 35-42.

67. Prokofieva, M. T. and Babkin, V. F. 1965. Hemagglutination properties of infectious laryngotracheitis virus of chickens. Veterinarija (Moscow) 42: 24-28 (in Russian).

68. Rauh, I. and Mettenleiter, T. C. 1991. Pseudorabies virus glycoprotein $\mathrm{gII}$ and $\mathrm{gp} 50$ are essential for virus penetration. J. Virol. 65: 5348-5356.

69. Roizman, B. 1991. Herpesviridae. pp. 103-110. In: Classification and Nomenclature of Viruses (Francki, R. I. B., Fauquet, C. M., Knudson, D. L., Brown, F. eds.), Springer, Wien New York, (Arch. Virol. Suppl. 2).

70. Rota, P. A., Maes, P. K. and Ruyechan, W. T. 1986. Physical characterization of the genome of feline herpesvirus-1. Virology 154: 168-179.

71. Sato, E., Yokoyama, N., Maeda, K., Inoshima, Y., Kohmoto, M., Ikeda, Y., Miyazawa, T. and Mikami, T. 1998. Construction of a recombinant feline herpesvirus type 1 vaccine expressing Gag precursor protein of feline immunodeficiency 
virus. Arch. Virol. (in press)

72. Schmidt, J., Klupp, B. G., Karger, A. and Mettenleiter, T. C. 1997. Adaptability in herpesviruses: glycoprotein D-independent infectivity of pseudorabies virus. J. Virol. 71: 17-24.

73. Scott, F. W. 1975. Evaluation of a feline viral rhinotracheitis vaccine. Feline Prac. 5: 17-22.

74. Scott, F. W. 1977. Evaluation of a feline viral rhinotracheitisfeline calicivirus disease vaccine. Am. J. Vet. Res. 38: 229-234.

75. Slater, E. and York, C. 1976. Comparative studies on parental and intranasal inoculation of an attenuated feline herpesvirus. Dev. Biol. Standard. 33: 410-416.

76. Spatz, S. J. and Maes, R. K. 1993. Immunological characterization of the feline herpesvirus-1 glycoprotein B and analysis of its deduced amino acid sequence. Virology 197: 125-136.

77. Spatz, S. J., Rota, P. A. and Maes, R. K. 1994. Identification of the feline herpesvirus type 1 (FHV-1) genes encoding glycoproteins G, D, I and E: expression of FHV-1 glycoprotein $\mathrm{D}$ in vaccinia and racoon poxviruses. J. Gen. Virol. 75: 12351244.

78. Strandberg, J. D. and Aurelian, L. 1969. Replication of canine herpesvirus. II. Virus developement and release in infected dog kidney cells. J. Virol. 4: 480-489.

79. Studdert, M. J. and Martin, M. C. 1970. Virus diseases of the respiratory tract of cats: 1 . Isolation of feline rhinotracheitis virus. Aust. Vet. J. 46: 99-104.

80. Sussman, M. D., Maes, R. K., Kruger, J. M., Spatz, S. J. and Venta, P. J. 1995. A feline herpesvirus-1 recombinant with deletion in the genes for glycoproteins $\mathrm{gI}$ and $\mathrm{gE}$ is effective as a vaccine for feline thinotracheitis. Virology 214: 12-20.

81. Tegtmeyer, P. and Enders, J. F. 1969. Feline herpesvirus infection in fused cultures of naturally resistant human cells. $J$. Virol. 3: 469-476.

82. Tetsu, N., Inaba, Y., Yukawa, M., Yoshiki, K., Hirahara, T., Furuya, Y., Ito, S., Yoneuchi, A. and Ishikawa, H. 1989. Hemagglutination with pseudorabies virus. Arch. Virol. 106: 321-326.

83. Tham, K. M. and Studdert, M. J. 1986. Variable sensitivity of a feline embryo cell line and three kitten kidney cell cultures to feline herpes- and caliciviruses. Vet. Microbiol. 11: 173176.

84. Trybala, E., Larski, Z. and Wisniewski, J. 1990. Hemagglutination by herpes simplex virus type 1. Arch. Virol. 113: 89-94.

85. Trybala, E., Svennerholm, B., Bergstrom, T., Olofsson, S., Jeansson, S. and Goodman, J. L. 1993. Herpes simplex virus type 1-induced hemagglutination: glycoprotein $\mathrm{C}$ mediates virus binding to erythrocyte surface heparan sulfate. J. Virol. 67: 1278-1285.

86. Verschoor, E. J., Willemse, M. J., Stam, J. G., Van Vliet, A. L. W., Pouwels, H., Chalmers, S. K., Horzinek, M. C., Sondermeijer, P. J. A., Hesselink, W. and De Ronde, A. 1996.
Evaluation of subunit vaccines against feline immunodeficiency virus infection. Vaccine 14: 285-289.

87. Wardley, R. C., Berlinski, P. J., Thomsen, D. R., Meyer, A. L. and Post, L. E. 1992. The use of feline herpesvirus and baculovirus as vaccine vectors for the gag and env genes of feline leulaemia virus. J. Gen. Virol. 73: 1811-1818.

88. Wardley, R. C., Gaskell, R. M. and Povey, R. C. 1974. Feline respiratory viruses- their prevalence in clinically healthy cats. J. Small Anim. Pract. 15: 579-586.

89. Willemse, M.J., Chalmers, W.S.K. and Sondermeijer, P.J.A. 1996. In vitro properties of a feline herpesvirus type 1 mutant carrying a lacZ insertion at the gI locus of the unique short segment. Vaccine 14: 1-5.

90. Willemse, M. J., Chalmers, W.S.K., Cronenberg, A.M., Pfundt, R., Strijdveen, I. G. L. and Sondermeijer, P. J. A. 1994. The gene downstream of the $\mathrm{gC}$ homologue in feline herpes virus type 1 is involved in the expression of virulence. J. Gen. Virol. 75: 3107-3116.

91. Willemse, M. J., Strijdveen, I. G. L., van Schooneveld, S. H. B., van den Berg, M. C. and Sondermeijer, P. J. A. 1995. Transcriptional analysis of the short segment of the feline herpesvirus type 1 genome and insertional mutagenesis of a unique reading frame. Virology 208: 704-711.

92. Wilson, J. H. G. 1978. Intranasal vaccination against upper respiratory tract disease (URD) in the cat. II. Results of field studies under enzootic conditions in the Netherlands with a combined vaccine containing live attenuated calici- and herpesvirus. Comp. Immunol. Microbiol. Infect. Dis. 1: 43-48.

93. Yagami, K., Furukawa, T. and Fukui, M. 1985. Serologic and virologic surveys on feline herpesvirus and feline calicivirus infections in cats for experimental use. Exp. Anim. (Tokyo) 34: 241-248.

94. Yagami, K., Furukawa, T., Fukui, M. and Hamada, H. 1985. Evaluation of tri-combinant vaccine for feline herpesvirus, calicivirus and panleukopenia virus infection in Japanese native cats. Exp. Anim. (Tokyo) 34: 287-294.

95. Yokoyama, N., Maeda, K., Tohya, Y., Kawaguchi, Y., Fujita, K. and Mikami, T. 1996. Recombinant feline herpesvirus type 1 expressing immunogenic proteins inducible virus neutralizing antibody against feline calicivirus in cats. Vaccine 14: $1657-1663$.

96. Yokoyama, N., Maeda, K., Fujita, K., Ishiguro, S., Sagawa, T., Mochizuki, M., Tohya, Y. and Mikami, T. 1996. Vaccine efficacy of a recombinant feline herpesvirus type 1 expressing immunogenic proteins of feline calicivirus in cats. Arch. Virol. 141: 2339-2351.

97. Yokoyama, N., Maeda, K. and Mikami, T. 1997. Recombinant viral vector vaccines for the veterinary use. [Review] $J$. Vet. Med. Sci. 59: 311-322. 